\title{
PROFESIONALISME MAHASISWA AKUNTANSI dan MAHASISWADMINISTRASI BISNIS DALAM MENGOPERASIKAN APLIKASI KOMPUTER AKUNTANSI
}

\author{
Suharyono* \\ Politeknik Negeri Bengkalis, Jalan Bathin Alam, Desa Sungai Alam, Kabupaten Bengkalis, 28714, Provinsi Riau, Indone- \\ sia \\ suharyono@polbeng.ac.id
}

\author{
A R T I C L E I N F O \\ Article history: \\ Received March 10, 2019 \\ Revised April 4, 2019 \\ Accepted April17, 2019
}

Key words:

Comparison, Score, Computer, Accounting, Students

\begin{abstract}
A B S T R A C T
The decision of the Minister of Manpower and Transmigration Number 182 of 2013 concerning the Establishment of Indonesian National Work Competency Standardsstates that one of the competency units that accountants must possess is operating an accounting computer application. This research was conducted to prove and compare the results of competency tests, especially the units operating accounting computer applications between students of the Accounting Department and Business Administration Department. The test tool used was the Mann-Whiteney nonparametric test. The sample in this study amounted to 104 students, consisting of: 52 Accounting Department students and 52 Business Administration students. The results of this study indicate that the competence to operate accounting computer applications between students of the Accounting Department and Business Administration Department has a significant difference
\end{abstract}

A B S T R A K

Keputusan Menteri Tenaga Kerja dan Transmigrasi Nomor 182 Tahun 2013 tentang Penetapan Standar Kompetensi Kerja Nasional Indonesia menyatakan bahwa salah satu unit kompetensi yang harus dimiliki akuntan adalah mengoperasikan aplikasi komputer akuntansi. Penelitian ini dilakukan untuk membuktikan dan membandingkan hasil uji kompetensi, terutama unit yang mengoperasikan aplikasi komputer akuntansi antara mahasiswa Departemen Akuntansi dan Departemen Administrasi Bisnis. Alat uji yang digunakan adalah uji nonparametrik Mann-Whiteney. Sampel dalam penelitian ini berjumlah 104 siswa, yang terdiri dari: 52 mahasiswa Jurusan Akuntansi dan 52 mahasiswa Administrasi Bisnis. Hasil penelitian ini menunjukkan bahwa kompetensi untuk mengoperasikan aplikasi komputer akuntansi antara mahasiswa Jurusan Akuntansi dan Departemen Administrasi Bisnis memiliki perbedaan yang signifikan.

\section{PENDAHULUAN}

Keputusan Menteri Tenaga Kerja dan Transmigrasi Nomor 182 Tahun 2013 Tentang Penetapan Standar Kompetensi Kerja Nasional Indonesia kategori jasa profesional, ilmiah, dan teknis golongan pokok jasa hukum dan akuntansi golongan jasa akuntansi, pembukuan dan pemeriksa; konsultasi pajak sub golongan jasa akuntansi, pembukuan dan pemeriksa; konsultasi pajak kelompok usaha teknisi akuntansi telah menjadi acuan penyelenggaraan pendidikan dan pelatihan profesi, uji kompetensi dan sertifikasi profesi. Perkembangan industri dan dunia usaha harus senantiasa diikuti oleh jasa akuntansi yang mempunyai peranan sebagai bahasa bisnis untuk menyampaikan informasi tentang perusahaan dalam bentuk pelaporan keuangan. Profesi Teknisi Akuntansi berfungsi membantu tugas akuntan dalam mengolah data transaksi suatu entitas sampai dengan menyajikannya dalam bentuk pelaporan keuangan. Pelaporan keuangan yang disajikan sangat berguna bagi para pengguna untuk proses pembuatan keputusan. Hal ini menuntut bahwa pelaporan yang diberikan kepada para pengguna tersebut harus disajikan dengan benar dan wajar. Supaya pelaporan tersebut memenuhi kaidah kebenaran dan kewajaran, tentunya memerlukan orang-orang yang berkompeten untuk menghasilkan pelaporan keuangan.

Agar dapat bekerja dan melaksanakan fungsi jasa teknisi akuntansi secara profesional, maka tenaga kerja yang berkecimpung di bidang akuntansi harus memiliki basis kompetensi berstandar nasional dan internasional. Hal ini dapat dicapai melalui pendidikan, pelatihan, dan pen- 
galaman dalam rangka meningkatkan kompetensi para teknisi akuntansi yang mencakup knowledge (pengetahuan), skills (ketrampilan), dan attitude (sikap kerja).

Salah satu unit kompetensi yang harus dimiliki akuntan adalah mengoperasikan aplikasi komputer akuntansi. Unit kompetensi ini berkaitan dengan ketrampilan, pengetahuan dan sikap kerja yang dibutuhkan dalam mengoperasikan aplikasi komputer akuntansi sesuai dengan prosedur yang ditetapkan pada perusahaan. Unit ini terdiri atas lima elemen kompetensi yaitu: menyiapkan data awal perusahaan, menyusun data setup awal/saldo awal, melakukan entry transaksi, mencetak laporan keuangan/laporan lainnya dan membuat backup file (Suharyono dan Widodo, 2017). Pengetahuan dan keterampilan yang diperlukan pada tingkatan ini harus mempertunjukkan suatu pemahaman dasar pengetahuan yang luas mengenai beberapa konsep teoritis, kebijakan organisasi dan memeriksa prosedur yang berlaku, pengoperasian program aplikasi komputer akuntansi, menyimpan dan membackup file, mengetik, literasi komputer, kemampuan dalam matematika untuk analisis dan kalkulasi keuangan. Permasalahan yang perlu diperhatikan pada kompetensi mengoperasikan akuntansi komputer meliputi: kebenaran dalam mempersiapkan data awal perusahaan, kebenaran dalam membuat bagan akun (chart of account), kebenaran dalam membuat buku pembantu, keakuratan dalam mengentry saldo awal dan transaksi, kebenaran dalam mencetak laporan, kebenaran dalam membuat backup file.

Penelitian tentang kompetensi akuntansi ini telah dilakukan sebelumnya untuk mengetahui apakah terdapat perbedaan hasil belajar dalam mata kuliah komputer akuntansi antara kelas A, B dan C. Hasil penelitian ini menunjukkan bahwa hasil belajar atau kemampuan mahasiswa dalam mata kuliah komputer akuntansi dengan menggunakan MYOB antara kelas A, kelas B dan kelas $C$ tidak berbeda. Perbedaan dosen yang mengampu mata kuliah komputer akuntansi disetiap kelas tidak berpengaruh terhadap hasil belajar mahasiswa (Suharyono dan Widodo, 2017). Kompetensi merupakan kemampuan bersikap, berfikir dan bertindak secara konsisten sebagai perwujudan dari nilai pengetahuan dan keterampilan yang dimiliki seseorang dalam melaksanakan pekerjaan. Kebutuhan akan sumberdaya manusia yang kompeten saat ini, merupakan sesuatu yang mendesak untuk disikapi, hal ini disebabkan semakin tingginya tingkat persaingan di semua bidang kehidupan.
Adel dan Manik (2018) melakukan penelitian untuk menganalisis dan memberikan solusi kelayakan fasilitas laboratorium produktif akuntansi Fakultas Ekonomi UMRAH. Hasil penelitian ini adalah ruangan laboratorium akuntansi Fakultas Ekonomi UMRAH belum memenuhi standar sebagai laboratorium akuntansi dianalisis berdasarkan, fasilitas, keaslian aplikasi (software), sistem LAN dan kondisi ruangan, analisis perubahan rangkaian posisi komputer cleint mahasiswa dan dosen. Analisis solusi pengembangan dan pengelolaan laboratorium akuntansi lebih utama pada penataan tempat komputer, server, jaringan LAN dan instalasi komputer yang aman sehingga akan lebih efisien dan efektif digunakan selama proses belajar dan mengajar, sehingga dosen lebih mudah memantau proses dan hasil praktikum komputer akuntansi dalam ruang belajar laboratorium.

Suharyono dan Satria (2015) melakukan penelitian yang berjudul pengaruh konten dan kemudahan pemakaian dalam Bahasa Inggris terhadap pemahaman pemakai software myob accounting (studi empiris pada mahasiswa semester V Program Studi Administrasi Bisnis Politeknik Negeri Bengkalis). Hasil penelitian menunjukkan bahwa variabel konten dan kemudahan pemakaian software dalam bahasa inggris secara simultan mempengaruhi pemahaman pemakai software $M Y$ $O B$ accounting .Variabel konten software MYOB accounting dalam bahasa inggris secara parsial berpengaruh terhadap pemahaman pemakai software $M Y O B$ accounting. Variabel kemudahan pemakaian software $M Y O B$ accounting secara parsial berpengaruh terhadap pemahaman pemakai software $M Y O B$ accounting, sedangkan variabel koefisien determinasi menunjukkan bahwa 47,3\% pemahaman pemakai software MYOB accounting dipengaruhi oleh konten dan kemudahan pemakaian dalam Bahasa Inggris.

Suharyono (2019) juga meneliti pengaruh MYOB test clinic terhadap kompetensi mahasiswa. Tujuannya adalah untuk membuktikan pengaruh pelaksanaan $M Y O B$ test clinic terhadap peningkatan kompetensi mahasiswa pada Program Studi D4 Akuntansi Keuangan Publik. Data yang digunakan dalam penelitian ini adalah data primer yang diperoleh dari penyebaran kuesioner.

Responden penelitian ini adalah mahasiswa Prodi D4 Akuntansi Keuangan Publik yang berjumlah 52 responden. Metode analisis data yang digunakan adalah analisis statistik regresi berganda. Berdasarkan hasil evaluasi pelaksanaan $M Y O B$ test clinic, nilai rata-rata yang diperoleh terjadi peningkatan yaitu dari sebelumnya 48 menjadi 74 atau 
meningkat 52\%. Hasil penelitian menunjukkan bahwa variabel metode, materi, instruktur $M Y O B$ test clinic tidak berpengaruh terhadap kompetensi mahasiswa pada Program Studi D4 Akuntansi Keuangan Publik. Kontribusi pengaruh variabel metode, materi, dan instruktur MYOB test clinic terhadap kompetensi mahasiswa hanya sebesar 1,9\% dan sisanya sebesar 98,1\% dipengaruhi oleh variabel-variabel yang lain.

Penelitian ini bertujuan untuk membuktikan dan membandingkan hasil uji kompetensi mengoperasikan aplikasi komputer akuntansi antara mahasiswa Jurusan Akuntansi dengan Jurusan Administrasi Bisnis. Penelitian ini memiliki urgensi untuk dijadikan arah dan landasan untuk mengembangkan indikator pencapaian ketuntasan belajar, penerapan kurikulum, serta pengembangan materi pokok dalam kegiatan pembelajaran yang berhubungan dengan kompetensi mengoperasikan aplikasi komputer akuntansi. Selain itu, standar proses dan standar evaluasi baik evaluasi pembelajaran maupun evaluasi hasil belajar merupakan hal yang perlu diperhatikan dalam merancang kegiatan pembelajaran. Di era kemajuan teknologi dan informasi saat ini, harus dihasilkan akuntan yang profesional dibidang akuntansi berbasis komputer.

\section{KAJIAN LITERATUR DAN PENGEMBANGAN HIPOTESIS}

Penelitian ini berkaitan dengan profesi akuntan. Penelitian ini melihat kompetensi yang telah dicapai melalui aspek perbedaan program studi. Untuk itu landasan teori atau teori dasar penelitian ini adalah teori sosiologi Kalbers dan Fogarty (1995) dan teori sosiologi klasik Aranya dan Ferris (1983). Teori tersebut menyatakan bahwa masyarakat mengakui kekuatan (power) dan prestise profesi karena para profesional memiliki ilmu pengetahuan yang terkait dengan kebutuhan dan nilai-nilai sentral dari sistem sosial. Oleh karena itu, menurut Vollmer dan Mills (1966), Moore (1970), Larson (1977), dalam Aranya dan Ferris (1983) dalam hasil penelitiannya menyatakan bahwa masyarakat mengharapkan para profesional untuk berkomitmen melayani masyarakat di atas kepentingan pribadinya dan melebihi insentifinsentif material.

\section{Mengoperasikan Aplikasi Komputer Akuntansi}

Peraturan Presiden Nomor 08 tahun 2012, tentang Kerangka Kualifikasi Nasional Indonesia (KKNI), merupakan acuan yang bersifat legal formal dalam penataan kualifikasi nasional dalam bidang ketenagakerjaan. Perpres ini juga menjadi rujukan bagi dunia pendidikan dan lembaga pelatihan dalam merumuskan kurikulum dan program pelatihan, bagi lembaga sertifikasi profesi dalam melaksanaan sertifikasi kompetensi (uji kompetensi) dan merumuskan lingkup (skema sertifikasi), dan bagi dunia industri dalam proses rekruitment terutama terkait dengan pengakuan tingkat kualifikasi tenaga kerja yang dibutuhkan.

Perkembangan industri dan dunia usaha harus senantiasa diikuti oleh jasa akuntansi yang mempunyai peranan sebagai bahasa bisnis untuk menyampaikan informasi tentang perusahaan dalam bentuk pelaporan keuangan. Profesi teknisi akuntansi berfungsi membantu tugas akuntan dalam mengolah data transaksi suatu entitas sampai dengan menyajikannya dalam bentuk pelaporan keuangan. Pelaporan keuangan yang disajikan sangat berguna bagi para pengguna untuk prosespembuatan keputusan. Hal ini menuntut bahwa pelaporan yang diberikankepada para pengguna tersebut harus disajikan dengan benar dan wajar.Supaya pelaporan tersebut memenuhi kaidah kebenaran dan kewajaran, tentunya memerlukan orang-orang yang berkompeten untuk menghasilkanpelaporan keuangan tersebut.

Agar dapat bekerja dan melaksanakan fungsi jasa teknisi akuntansi secara profesional, maka tenaga kerja yang berkecimpung di bidang ini harus memiliki basis kompetensi berstandar nasional dan internasional. Hal Ini dapat dicapai melalui pendidikan, pelatihan, dan pengalaman dalam rangka meningkatkan kompetensi para teknisi akuntansi yang mencakup knowledge (pengetahuan), skills (ketrampilan), dan attitude (sikap kerja). Selain itu, aspek penting dalam menilai sampai sejauhmana kompetensi tersebut telah dicapai maka diperlukan standar kompetensi dari teknisi akuntansi. Dengan adanya standar kompetensi, maka SDM yang belum mencapai standar harus meningkatkan kemampuannya sehingga memenuhi standar yang ditetapkan.

Dalam menyikapi perubahan dunia bisnis dibutuhkan tenaga yang memenuhi standar kualifikasi tertentu. Untuk menetapkan standar kualifikasi tenaga kerja seperti pada bidang akuntansi, perlu adanya hubungan timbal balik antara pihak industri/usaha sebagai pengguna tenaga kerja, dengan pihak pendidikan dan latihan formal maupun non formal yang menghasilkan tenaga kerja. Kerjasama tersebut untuk merumuskan standar kualifikasi tenaga kerja sehingga bisa dihasilkan tenaga kerja yang 
diinginkan oleh dunia usaha/industri. Standar tersebut berisi rumusan kemampuan kerja pada bidang akuntansi yang mencakup aspek pengetahuan, ketrampilan dan sikap kerja dalam melaksanakan pekerjaan sesuai tugas dan jabatan yang diakui secara nasional.Kemampuan kerja yang memenuhi ketiga aspek tersebut dinyatakan sebagai kompetensi, oleh karenanya disebut standar kompetensi kerja.

Undang-Undang Nomor 13 Tahun 2003 tentang Ketenagakerjaan juga mengatur bahwa pelatihan kerja diselenggarakan berdasarkan programpelatihan yang mengacu pada standar kompetensi kerja (Pasal 10). Disebutkan dalam undang-undang bahwa kompetensi tenaga kerja terbentuk dari tiga ranah (domain), yaitu ranah pengetahuan (kognitif), ranah ketrampilan (psikomotor), dan ranah sikap (afektif). Tiga ranah itu masing-masing berkaitan dengan kemampuan daya pikir, kemampuan menggerakkan anggota badan dengan metode atau teknik tertentu, dan kemampuan mengekspresikan kemauan diri Secara ringkas, kompetensi tersebut didefinisikan sebagai penguasaan disiplin keilmuan dan pengetahuan serta ketrampilan menerapkan metode atau teknik tertentu yang didukung sikap perilaku yang tepat guna mencapai dan/atau mewujudkan hasil tertentu dalam penyelenggaraan tugas pekerjaan.

Mengoperasikan aplikasi komputer akuntansi merupakan salah satu unit kompentensi yang wajib diikuti oleh asesi untuk menjadi teknisi akuntansi yunior. Mahasiswa dituntut untuk menguasai sifat pekerjaan seperti mampu melaksanakan satu tugas spesifik dengan menggunakan alat/informasi/prosedur kerja yang lazim dilakukan, memiliki pengetahuan operasional dasar, memiliki pengetahuan faktual bidang kerja yang spesifik, dan memiliki tanggung jawab pada pekerjaan sendiri dan dapat diberi tanggung jawab membimbing orang lain.

Lingkup aktivitasnya yaitu mampu menjadi teknisi akuntansi yunior yang profesional dan mampu melakukan pekerjaan di bidang akuntansi pada perusahaan (entitas) jasa dan/atau dagang berskala kecil (mikro) dan/atau entitas tanpa akuntabilitas publik (ETAP) yang sesuai dengan prinsip akuntansi berlaku umum dan relevan di bidang akuntansi, melalui proses pengidentifikasian data dan pemilihan metode yang sesuai, di dukung dengan kemampuan di bidang, teknologi informasi, keahlian interpersonal dan komunikasi.

\section{Sistem Infomasi Akuntansi}

Sistem informasi akuntansi (SIA) yang terdiri dari manusia, prosedur dan teknologi informasi. SIA dalam organisasi berfungsi untuk mengumpulkan dan menyimpan data aktifitas dan transaksi sehingga organisasi dapat melihat apa yang telah terjadi dalam kegiatan usahanya. SIA juga bermanfaat untuk mengolah data menjadi informasi yang berguna bagi pengambilan keputusan sehingga memungkinkan manajemen untuk melakukan aktifitas perencanaan, implementasi dan pengendalian. Selain itu, SIA yang efektif mampu menyediakan pengendalian yang cukup untuk mengamankan asset organisasi termasuk data. Pengendalian ini dibutuhkan untuk menjamin bahwa data tersedia pada waktudibutuhkandan data tersebut akurat, dan dapat diandalkan.

Fokus utama istem informasi akuntansi adalah bagaimana sistem akuntansi bekerja mulai dari bagaimana mengumpulkan data, bagaimana mengolah data menjadi informasi yang berguna bagi manajemen, dan bagaimana menjamin bahwa informasi yang dihasilkan adalah akurat dan dapat diandalkan. Sistem informasi akuntansi akan menyediakan informasi yang dibutuhkan oleh pemakai informasi.

\section{Profesionalisme}

Berdasarkan dari hasil penelitian sebelumnya yang dilakukan dengan membedakan orang menjadi pekerja profesional dan tidak profesional yang dikategorikan berdasarkan jenis pekerjaan seseorang. Howell dan Dorfman (1986) dalam Swailes (2003), membuat tujuh skala untuk mengukur tingkat profesionalisme kerja seseorang adapun indikatornya ialah pendidikan, tingkat kemampuan dalam melakukan suatu pekerjaan, kehandalan dalam mengevaluasi kinerja, panduan, dan interkasi dengan orang-orang yang memiliki profesi yang sama, serta kebutuhan terhadap otonomi. Dalam pengukuran tingkat profesioanlisme tersebut masih dirasa tidak mengukur dengan kejelasan yang cukup terhadap sikap dan ideologi para profesional yang dijadikan objek.

Kontribusi utama terhadap penelitian mengenai tingkat profesionalisme ini datang dari Hall (1968) dalam Novryandana (2015) yang mengukur profesionalisme dengan menitikberatkan pada perilaku. Kemudian hasil penelitian Hall (1968) ini diuji kembali oleh Snizek (1972), yang menemukan bahwa hanya setengah dari skala item profesional yang dikemukakan oleh 
Hall yang dianggap memadai sebagai pengukur profesionalisme. Seiring dengan perkembangan zaman akhirnya hasil temuan Snizek (1972) melalui Teori Hall (1968) mengenai profesionalisme terus digunakan oleh para peneliti selanjutnya dan pada akhirnya dapat digeneralisasi, yang terbukti salah satunya di Amerika utara.

Di Indonesia penelitian yang berkaitan dengan profesi akuntan datang dari Novriyandana (2015) yang mengukur profeionalisme akuntan dari segi sex. Hasil penelitian ini, jika dilihat profesionalisme auditor dari sex tidak ditemukan perbedaan profesionalisme, artinya antara pria dan wanita memiliki tingkat profesionalisme yang sama sebagai akuntan.

Berdasarkan landasan teori dan penelitian terdahulu telah dijelaskan tentang pentingnya kompetensi yang dimiliki mahasiswa khususnya dibidang mengoperasikan aplikasi komputer akuntansi untuk mendukung lahirnya profesionalprofesional muda yang memiliki kompetensi yang mumpuni. Oleh karena itu, penelitian ini penting untuk mengukur kompetensi mahasiswa Jurusan Akuntansi dan mahasiswa Jurusan Administrasi Bisnis sehingga diperoleh bukti empiris tentang perbedaan kompetensi akuntansi yang dimiliki oleh mahasiswa dilihat dari perbedaan jurusan.

\section{Hipotesis}

Hipotesis dalam penelitian ini adalah mahasiswa jurusan akuntansi memiliki tingkat profesionalisme yang lebih tinggi dibandingkan mahasiswa jurusan administrasi bisnis dalam mengoperasikan aplikasi komputer akuntansi.

\section{METODE PENELITIAN}

\section{$\underline{\text { Data Penelitian }}$}

Penelitian ini menggunakan data sekunder. Data sekunder adalah data yang telah dikumpulkan melalui uji kompetensi mengoperasikan aplikasi komputer akuntansi. Data sekunder berupa nilai akhir mahasiswa dalam uji kompetensi mengoperasikan aplikasi komputer akuntansi yang diselenggarakan pada tahun 2018.

\section{Sampel}

Populasi penelitian ini ialah seluruh mahasiswa Jurusan Akuntansi dan Jurusan Administrasi Bisnis yang berada di Pulau Sumatera. Sampel yang dipakai yaitu mahasiswa yang memenuhi syarat atau kriteria sebagai objek penelitian. Metode pemilihan sampel dilakukan dengan clustered sampling berdasarkan Indriantoro dan Supono (1999), yaitu dengan membagi sampel penelitian menjadi kelompokkelompok berdasarkan perbedaan jurusan.

\section{Variabel Penelitian}

Variabel yang digunakan dalam penelitian ini hanya 1 (satu) variabel, yaitu nilai akhir komputer akuntansi.Nilai akhir merupakan hasil uji kompetensi akuntansi berbasis komputer. Variabelvariabel yang diukur dari masing-masing item kompetensi yaitu:

1. Menyiapkan data awal perusahaan, seperti membuat profil perusahaan, periode akuntansi, jenis usaha dan membuat user id/password,

2. Menyusun data setup awal dan saldo awal, seperti membuat nama barang, daftar supplier, daftar customer, daftar job, daftar pajak, dan daftar akun,

3. Melakukan entry transaksi, seperti mengentry jurnal pembelian, penjualan, penerimaan/ pengeluaran kas, dan jurnal penyesuaian,

4. Mencetak laporan keuangan dan laporan lainnya, dan

5. Membuat backup file.

\section{Instrumen Penelitian}

Instrumen pada penelitian ini merupakan modifikasi dari penelitian-penelitian sebelumnya. Intrumen yang digunakan yaitu observasi dan evaluasi.

\section{$\underline{\text { Alat } U_{j i}}$}

Alat uji yang digunakan untuk data normal adalah Independent Sample T-test. Rumus Independent Sample T-test dapat direpresentasikan sebagai berikut:

Keterangan:

$$
\mathrm{t}=(\mathrm{X}-\mu) /((\mathrm{SD} / \sqrt{ } \mathrm{N}))
$$

$$
\begin{aligned}
& \mathrm{t}=\text { nilai } \mathrm{t} \text { hitung } \\
& \mathrm{X}=\text { rata-rata sampel } \\
& \mu=\text { nilai parameter } \\
& \mathrm{SD}=\text { standar deviasi } \\
& \mathrm{N}=\text { sampel }
\end{aligned}
$$

Untuk data yang tidak normal, alat uji yang digunakan adalah uji beda non parametrik MannWhitney. Kedua alat uji ini berfungsi untuk membandingkan rata-rata dari dua grup yang tidak berhubungan satu dengan yang lain, apakah kedua kelompok tersebut mempunyai rata-rata yang sama atau tidak secara signifikan. Rumus Mann-Whitney sebagai berikut:

Keterangan: 
$\mathrm{U} 1$ = Statistik uji U1

$\mathrm{U} 2$ = Statistik uji U2

$\mathrm{R} 1$ = jumlah rank sampel 1

R2 = jumlah rank sampel 2

n1 = banyaknya anggota sampel 1

$\mathrm{n} 2$ = banyaknya anggota sampel 2

Kriteria pengujiannya untuk uji Independent Sample T-test adalah :

1. Apabila signifikansi lebih besar dari p-value (5\%), maka Ho ditolak,

2. Apabila nilai $t$ hitung lebih tinggi dibandingkan $\mathrm{t}$ tabel, maka $\mathrm{Ha}$ diterima, dan

3. Apabila nilai $t$ tabel lebih tinggi dibandingkan $\mathrm{t}$ hitung, maka Ho diterima.

Untuk uji beda non parametrik Mann Whitney U, kriteria pengambilan keputusannya adalah:

1. Apabila signifikansi lebih besar dari p-value (5\%), maka Ho ditolak,

2. Jika nilai $U$ hitung $\leq U$ table atau signifikansi diatas p-value maka Ho ditolak, Ha diterima, dan

3. Jika nilai $\mathrm{u}$ hitung $>\mathrm{u}$ table maka ho diterima.

\section{HASIL DAN PEMBAHASAN}

Analisis Deskriptif

Penelitian ini bertujuan untuk membuktikan dan membandingkan hasil uji kompetensi mengoperasikan aplikasi komputer akuntansi antara mahasiswa Jurusan Akuntansi dengan Jurusan Administrasi Bisnis.Hasil uji deskriptif disajikan dalam Tabel 1.

Tabel 1. Hasil UjiDeskriptif

\begin{tabular}{|l|l|l|l|l|l|}
\hline No & Jurusan & Mean & Min & Max & Median \\
\hline 1 & Akuntansi & 91,98 & 83 & 100 & 92 \\
\hline 2 & $\begin{array}{l}\text { Adm } \\
\text { Bisnis }\end{array}$ & 84,40 & 65 & 100 & 85 \\
\hline
\end{tabular}

Berdasarkan Tabel 1, rata-rata nilai akhir uji kompetensi mengoperasikan aplikasi komputer akuntansi untuk mahasiswa Jurusan Akuntansi adalah 91,98, lebih tinggi dibandingkan hasil uji kompetensi mahasiswa Jurusan Administrasi Bisnis yaitu 84,4.

Untuk nilai minimum, mahasiswa Jurusan Akuntansi mendapatkan nilai 83, sedangkan mahasiswa Jurusan Administrasi Bisnis nilai minimalnya adalah 65.Berdasarkan ketentuan uji kompetensi mengoperasikan aplikasi komputer akuntansi maka mahasiswa yang memperoleh nilai kurang dari 80 dinyatakan gagal atau tidak kompeten.
Dengan demikian, sebanyak 52 orang mahasiswa Jurusan Akuntansi dinyatakan kompeten seluruhnya, sedangkan untuk mahasiswa Jurusan Administrasi Niaga 10 orang dinyatakan tidak kompeten.

\section{$\underline{\text { Uji Normalitas }}$}

Pengujian normalitas data dilakukan dengan menggunakan Kolmogorov-Smirnov dengan alpha sebesar 5\%.Hasil uji normalitas data dapat dilihat pada Tabel 2.

Tabel 2. Hasil Uji Normalitas KolmogorovSmirnov

\begin{tabular}{|l|l|l|l|}
\hline No. & Jurusan & Sig & Keterangan \\
\hline 1 & Akuntansi & $0,1 \%$ & Tidak \\
2 & Adm Bisnis & $0,8 \%$ & Normal \\
& & & Tidak \\
& & & Normal \\
\hline
\end{tabular}

Hasil uji normalitas untuk nilai uji kompetensi mengoperasikan aplikasi komputer akuntansimahasiswa Jurusan Akuntansi adalah 0,1\% < 5\%. Artinya data berdistribusi tidak normal.Uji normalitas untuk nilai uji kompetensi mengoperasikan aplikasi komputer akuntansi mahasiswa Jurusan Administasi Bisnis adalah 0,8\% <5\%. Artinya data juga berdistribusi tidak normal.Dengan demikian, pengujian hipotesis hanya dapat dilakukan dengan menggunakan uji nonparametric Mann-Whiteney.

Mahasiswa Akuntansi Vs Administrasi Bisnis: Kompetensi Mengoperasikan Aplikasi Komputer Akuntansi

Pengujian hipotesis dilakukan dengan menggunakan uji Mann Whitney.Hasil uji hipotesisi dengan menggunakan uji Mann Whiteney dapat dilihat pada Tabel 3.

Tabel 3.Hasil Uji Mann-Whiteney

\begin{tabular}{|l|l|l|l|}
\hline No & Variabel & Sig & Keterangan \\
\hline 1 & Hasil belajar & 0,000 & Berbeda \\
\hline
\end{tabular}

Hasil uji Mann Whitney untuk melihat perbedaan uji kompetensi mengoperasikan aplikasi komputer akuntansi antara mahasiswa Jurusan Akuntansi dengan Jurusan Administrasi Bisnis menunjukkan signifikansi sebesar $0 \%$. Signifikansi tersebut lebih kecil dari p value 5\%, maka dapat disimpulkan hipotesa nol ditolak yang artinya kompetensi mengoperasikan aplikasi komputer akuntansi antara mahasiswa Jurusan Akuntansi dengan Jurusan Administrasi Bisnis memiliki perbedaan yang signifikan. 
Hasil penelitian ini telah mendukung hipotesis bahwa tingkat profesionalisme yang dimiliki mahasiswa Jurusan Akuntansi lebih tinggi dibandingkan mahasiswa Jurusan Administrasi Bisnis dalam mengoperasikan aplikasi komputer akuntansi. Seiring dengan intensnya materi-materi akuntansi yang diperoleh mahasiswa Jurusan Akuntansi telah berdampak bagi meningkatnya profesionalisme.

Penelitian ini juga sejalan dengan penelitian Novryandana (2015) bahwa terdapat perbedaan tingkat profesionalisme akuntan publik ditinjau dari jabatan atau amanah yang diembannya.perbedaan orientasi dalam pekerjaan mengakibatkan terjadiya perbedaan tersebut serta pengaruh intensitas dan flexibili tas pekerjaan merubah sikap, perilaku, dan etika auditor seiring dengan jabatan yang diembannya.

\section{SIMPULAN}

Penelitian ini bertujuan untuk membuktikan dan membandingkan hasil uji kompetensi mengoperasikan aplikasi komputer akuntansi antara mahasiswa Jurusan Akuntansi dengan Jurusan Administrasi Bisnis. Hasil penelitian ini menunjukkan bahwa kompetensi mengoperasikan aplikasi komputer akuntansi antara mahasiswa Jurusan Akuntansi dengan Jurusan Administrasi Bisnis memiliki perbedaan yang signifikan.

Hasil penelitian ini sejalan dengan hipotesis bahwa tingkat profesionalisme yang dimiliki mahasiswa Jurusan Akuntansi lebih tinggi dibandingkan mahasiswa Jurusan Administrasi Bisnis dalam mengoperasikan aplikasi komputer akuntansi. Seiring dengan intensnya materi-materi akuntansi yang diperoleh mahasiswa Jurusan Akuntansi telah berdampak bagi meningkatnya profesionalisme. Berdasarkan kesimpulan yang telah dikemukakan di atas, maka saran yang diajukan adalah penelitian selanjutnya diharapkan dapat menggunakan data primer, sehingga dapat menggali faktor-faktor yang menyebabkan kompetensi mahasiswa Jurusan Administrasi Bisnis lebih rendah dibandingkan Jurusan Akuntansi. Peneliti selanjutnya dapat juga membuat penelitian seperti ini dengan lebih menonjolkan pada seberapa tinggi tingkat profesionalisme dengan peringkat tinggi, rendah, dan sedang atau dengan penilaian A, B, C, dan D. Serta, mencari variabel-variabel yang dapat mempengaruhi peningkatan maupun penurunan tingkat profesionalisme.

\section{REFERENCES}

Adel, J. F., dan Manik, T., (2018), Sistem Pengembangan, Pengelolaan dan Fasilitas Laboratori- um Produktif Akuntansi dalam Meningkatakan Kualitas Komputer Akuntansi (Prodi Akuntansi Fakultas Ekonomi UMRAH). Jurnal Ilmiah Akuntansi dan Finansial Indonesia, Vol 2, No 1.

Aranya, dan Ferris, K., (1983), Organizationalprofessional conflict among U.S. and Israeli professional accountants, Journal of Social Psychology Vol 119, page 153-161

Indriantoro, N. dan Supomo, B., (1999), Metodologi Penelitian Bisnis, untuk Akuntansi dan Manajemen, Edisi pertama. Yogyakarta: BPFE.

Kalbers dan Fogarty, T., (1995), Profesionalismand lts Consequences: A Study of internal Aduitor, Journal of Practice \& Theory, Vol. 14 No. 1.

Keputusan Menteri Tenaga Kerja Dan Transmigrasi Nomor 182 Tahun 2013 tentang Penetapan Standar Kompetensi Kerja Nasional Indonesia Kategori Jasa Profesional, Ilmiah, dan Teknis Golongan Pokok Jasa Hukum dan Akuntansi Golongan Jasa Akuntansi, Pembukuan dan Pemeriksa; Konsultasi Pajak Sub Golongan Jasa Akuntansi, Pembukuan dan Pemeriksa; Konsultasi Pajak Kelompok Usaha Teknisi Akuntansi.

Novriyandana, R., (2015), Perbedaan Tingkat Profesionalisme Kerja Auditor Dilihat Dari Jenis Kelamin, Jabatan, dan Jenis Afiliasi Kantor Akuntan Publik. Jurnal InFestasi, Vol. 11 No 2, page 186 - 194.

Peraturan Presiden Nomor 08 tahun 2012, tentang Kerangka Kualifikasi Nasional Indonesia (KKNI)

Snizek. W., (1972), Hall's Professionalism Scale: An Empirical Reassessment. American Sociological Review.

Suharyono, (2019), Pengaruh MYOB Test Clinic Terhadap Kompetensi Mahasiswa, Jurnal Analisa Akuntansi dan Perpajakan.

Suharyono dan Widodo, T., (2017), Analisis Hasil Belajar Mahasiswa Dalam Mata Kuliah Komputer Akuntansi. Jurnal Inovasi Bisnis.

Suharyono dan Satria, A., (2015), Pengaruh Konten dan Kemudahan Pemakaian dalam Bahasa Inggris Terhadap Pemahaman Pemakai Software MYOB Accounting (Studi Empiris pada Mahasiswa Semester V Program Studi Administrasi Bisnis Politeknik Negeri Bengkalis). Prosiding Seminar Nasional Industri dan Teknologi, Politeknik Negeri Bengkalis, November 2015, page 1-8.

Swailes, S., (2003), Professionalism: Evolution and measurement. The Service Industrial Journal, Vol 23 No 2, page 130-149. 
PROFESIONALISME MAHASISWA AKUNTANSI dan MAHASISWADMINISTRASI BISNIS DALAM MENGOPERASIKAN APLIKASI KOMPUTER AKUNTANSI

OLEH: SUHARYONO

Undang-Undang Nomor 13 Tahun 2003 tentang

Ketenagakerjaan. 